\title{
Ignorance-exposing Vulnerable Involvement, The Trust-creating Practice that Makes Executives Job-competent
}

Reuven Shapira*

Western Galilee College, Akko, Israel

\begin{abstract}
Executives' acquisition of job competence suffers from power tempting its use to conceal their ignorance and associated incompetence as dark secrets and to survive in jobs by abuses and subterfuges. Such competence requires sensitivity to the unique contours of circumstances which inter alia require local know-how and phronesis (Greek for practical wisdom) unknown even to insider executives, as with promotion they take charge of unfamiliar units/functions. Ignorance-exposing vulnerable involvement in deliberations is required to gain employees' trust, to learn through know-how and phronesis sharing, and to become job-competent, but this requires jeopardizing one's authority until becoming job-competent. A multi-case study of five automatic processing plants by a managementeducated and experienced semi-native anthropologist untangles that only few of their outsider executives, 4 of 27 studied, chose such involvement and became job-competent. As the import of outsider executives is now common, this problem is worsening and calls for solutions that are suggested, besides recommendations for further study.
\end{abstract}

Keywords: Executive job-competence; Ignorance exposure; Vulnerable involvement; Outsider executives; multi-case longitudinal ethnography

\section{Introduction and Theory}

With the "practice turn" in the social sciences, organization studies rediscovered the concept of practice but major executives' practices that made them job-competent were missed. Ample literature was devoted to educating executives by management science theories and findings but Shotter and [1] concluded that

"...it is not the generalized knowledge of science that is required in prudently leading people and

Handling human affairs, but a special sensitivity to the unique contours of the circumstances in which leaders happen to operate each time [2].

They and many others emphasize the decisiveness of tacit knowhow and phronesis acquired by practicing jobs [3-11]. "Practical wisdom and judgment, rather than seen as "things" hidden inside the mind, are best talked of, we suggest, as emerging developmentally within an unceasing flow of activities, in which practitioners are inextricably immersed [12]. Wrote: "our knowing is ordinarily tacit, implicit in our patterns of action and our feel for the stuff with which we are dealing" and according to [13] learning "phronesis requires experience" (original emphasis), i.e., coping with tasks and challenges; know-how and phronesis are "constituted and reconstituted as actors engaged in the world of practice" [7]. However, executives can avoid unknown practices; Shotter and Tsoukas's "inextricably immersed" assertion is not valid for executives who may not immerse themselves in activities that expose their ignorance [14], while due to promotion or because of outsiderness [15] they take charge of functions/ units which they did not experience and have little if any of their tacit know-how and phronesis. This is especially true of outsiders [16-19]. They may learn the processes by which the products or services are produced, but might not learn how these processes function [20]. Such ignorance of tacit knowledge precludes honing broader abilities into sharper ones required for effective management [21]. To learn the tacit know-how and phronesis of unfamiliar functions/units, executives must engage, indwell, and assimilate in employees' problem-solving [22] as managerial problems are often incorrectly formulated and/or ill-defined, lacking essential information, and have no single correct answer; only trustful sincere cooperation with knowledgeable locals teach tacit know-how and phronesis and generate correct formulations and solutions [23].

However, locals' sincere cooperation with and help for the executive's learning requires her/his ignorance-exposing trust-creating vulnerable involvement $[24,25]$. Trustful relations between managers and employees are essential for knowledge sharing, learning, problemsolving, decision-making, and innovating [26,27]. Unfortunately, ignorance exposure required to create trust diminishes one's authority [14], hence executives often avoid it, use bluffs, abuses, and subterfuges to conceal and camouflage ignorance, and scapegoat others for their own mistakes and failures caused by ignorance. These low-moral deeds are dark secrets, i.e., their very existence is secret, veiled on organizations' dark side by conspiracies of silence [28-31]. A contrary example is CEO Grove's [32], hesitations and then admitting ignorance of computer programming to Intel's programmers when he wanted to learn it prior to leading a corporate transformation which required such know-how. Other explanations for ignorance exposure by executives are habitus [33], past successes [34] and prospects of successful learning due to referred expertise, expertise in other action domains that facilitates learning [35]. Ignorance-exposing vulnerable involvement leads to virtuous trust and learning cycles, ignorance-concealing detachment or seduction-coercion [36] causes opposite cycles, summarized thus:

*Corresponding author: The Western Galilee Academic College, Acre, Kibbutz Gan Shmuel, M.P. Hefer, Israel 3881000; Tel: 972-4632-0597; E-mail: shapi_ra@gan.org.il

Received December 18, 2015; Accepted January 02, 2016; Published January 12 2016

Citation: Shapira R (2015) Ignorance-exposing Vulnerable Involvement, The Trustcreating Practice that Makes Executives Job-competent. J Socialomics 5: 144. doi:10.4172/2167-0358.1000144

Copyright: (C) 2015 Shapira R. This is an open-access article distributed under the terms of the Creative Commons Attribution License, which permits unrestricted use, distribution, and reproduction in any medium, provided the original author and source are credited. 
Citation: Shapira R (2015) Ignorance-exposing Vulnerable Involvement, The Trust-creating Practice that Makes Executives Job-competent. J Socialomics 5: 144. doi:10.4172/2167-0358.1000144

Page 2 of 9

\begin{tabular}{|c|c|}
\hline \multicolumn{2}{|c|}{$\begin{array}{c}\text { Virtuous Trust and Learning Cycle versus Vicious Distrust and Ignorance } \\
\text { Cycle }\end{array}$} \\
\hline $\begin{array}{l}\text { Involvement habitus and/or much } \\
\text { Pertinent expertises encourages } \\
\text { executives' choice of ignorance } \\
\text { exposing vulnerable involvement }\end{array}$ & $\begin{array}{l}\text { Detachment habitus and/or little } \\
\text { pertinent expertises encourages } \\
\text { executives 'choice of either detachment } \\
\text { or coercive-seductive autocratic control } \\
\text { that conceals Ignorance }\end{array}$ \\
\hline $\begin{array}{l}\downarrow \\
\text { Ignorance exposure creates trust, } \\
\text { openness and knowledge sharing that } \\
\text { enhances executives' learning, correct } \\
\text { decisions, and successes }\end{array}$ & $\begin{array}{l}\text { Both choices causes distrust and } \\
\text { secrecy that inhibits executives' learning, } \\
\text { causing mistaken decisions, indecision, } \\
\text { failures, destructive conflicts, and use of } \\
\text { Subterfuges } \\
\qquad \downarrow\end{array}$ \\
\hline $\begin{array}{l}\text { Successes further the } \\
\text { Executives gain intera } \\
\text { Job-competence, enh } \\
\downarrow\end{array}$ & $\begin{array}{l}\text { The above furthers secrecy and } \\
\text { learning inhibition; further failures and } \\
\text { executives'\& incompetence encourages } \\
\text { conservatism } \\
\qquad \downarrow\end{array}$ \\
\hline $\begin{array}{l}\text { The resulting innovati } \\
\text { trust enhances learnir }\end{array}$ & $\begin{array}{l}\text { Conservatism spares some mistakes } \\
\text { but culture causes others \& minimal } \\
\text { learning from them, brain-drain, and } \\
\text { furthers a low-trust culture of secrecy } \\
\text { and ignorance concealment }\end{array}$ \\
\hline
\end{tabular}

[37] Called high-trust innovation-prone cultures "organic" as against conservative-prone cultures called "mechanic." The former are rarer, as suggest literatures on organizations' dark [38], rarity of effective managers [39,40], managerial low-moral careerism [41-43] and corporate cultures (below).

Executives may change a high-trust plant culture into a low-trust one $[44,45]$ or cause an opposite change [46].

A CEO may shape a high-trust culture among executives [47] but may not impact mid-levelers conforming to the field's contrary gravity [33] and/or shaping different units' cultures (Parker, 2000). Leader efforts to create high-trust cultures may take years $[48,49]$ and may fail if employees perceive managers as "out of touch" with organizational realities and detecting a lack of integrity, discrepancies between their policies, discourses, and practices [45,50,51]. Thus, a major question is how can this situation be changed so that executives will opt for ignorance-exposing vulnerable involvement, learn local know-how and phronesis and shape high-trust cultures which would minimize mismanagement and maximize efficiency, effectiveness, and innovation?

Answering this question requires ethnography that explains executives' choice of trust-creating ignorance exposure or it opposite. Anthropologists have untangled and explained the learning and uses and abuses of local know-how and phronesis but only on the shop floor level, not with regard to executives $[8,52]$ they never untangled executives' detachment aimed at concealing ignorance as [14] did regarding bureaucrats. Interviews cannot untangle such a choice which contradicts executives' efforts to maintain façades of trust relations and dialogue with employees [53,54] Uncovering the truth behind executives' façades and explaining it by their practice choices is not simple as local cultures differ widely concerning trust-creating components of benevolence, competence, integrity, and predictability [55]. What may be considered an executive's benevolence in a paternalistic culture is perceived differently in a non-paternalistic one [56]. What is grasped as competent management differs according to technological sophistication and educational level of actors [52]. Consistent and predictable managerial decisions create trust in a routine, mature technology unit, but not in a novel technology, innovative firms, and R\&D units [37]. Likewise, perceived executives' integrity is impacted by perceived morality according to cultural norms $[26,57,58]$ and by the perceived compatibility between their deeds and words $[45,50]$.

Ethnography may explain executives' choices and their acquisition of local know-how and phronesis but regular participant observation as an employee is insufficient; one has to become an insider-outsider among executives, untangling their levels of expertise [4] and referred expertise [35], which impact their ignorance exposure/concealment choices [16]. One must reveal how these impact personal strategies and for this s/he needs a managerial education [59], managerial experience [5], and referred expertise that enhances learning of local practices and their language and acquiring interactional expertise, that is, expertise that enables fruitful communication with experts [60-62]. I have managerial education and experience, in addition to experience with agricultural and industrial equipment operation and anthropological research, which by longitudinal semi-native multi-case ethnography enabled me to untangle and explain executives' choices. I discerned the few who became job-competent by trustful vulnerable involvement from the majority who avoided it, explained the choices of both types by personal and contextual factors, and explained the majority's job survival and career advancement. This helped me propose solutions to this major problem.

The findings have three sections: 1 . Longitudinal semi-native anthropology: method and cases. 2. A summary of previously published findings on managerial ignorance. 3. Managerial learning and job-competence: trust-creating ignorance-exposing vulnerable involvement.

\section{Longitudinal semi-native anthropology: method and cases}

Anthropologists have rarely studied executives [63] as they face a major barrier: they cannot be executives and thus heed the advice of sages of old: "don't judge others until you have stood in their shoes"; field-work as an employee [52] or an observer-interviewer [28] cannot achieve this. I overcame this barrier by a unique semi-native longitudinal anthropology: A native anthropologist studies his/her own people and being too close to them s/he may adopt their biased or particularistic views [64], while outsider ethnographers often miss locals' sincere views and/or other decisive insiders' knowledge [65]. I avoided both by studying five automatic cotton gin plants and their parent inter-kibbutz regional cooperatives (I-KRCs), each owned by dozens of kibbutzim and managed by their members called pe'ilim (singular: $p a^{\prime} i l$ ). Like them I was a kibbutz member, had a college managerial education and had experienced for 18 years work and management at my kibbutz's automatic processing plant that partially resembled the five cotton gin plants studied, hence enjoying much referred expertise; I knew some pe'ilim even before the study, as well as the kibbutz context that socialized them $[66,67]$ usually organizational ethnographers lacked such knowledge [59]. I approached pe'ilim as their peer and interviews often turned into openly discussed common problems and I gained access to their documents. I entered the field as an anthropologist, without choosing a research design in advance, aiming at thick description [68] based on variegated data collected while participating in local life and sensing subjects' feelings, building mutual trust with informants, and achieving openness such that my analysis is based on complete, reliable, accurate, and sincere information.

\section{The focal plant and the case studies}

For five years I intermittently visited the focal Merkaz highcapacity automatic cotton gin plant (a pseudonym, as are all names hereafter) and its I-KRC's industrial park, holding both casual talks and 
lengthy open interviews of up to an hour and a half with 168 current and former plant managers (hereafter PMs) and staff plus 24 executives of its parent I-KRC, both pe'ilim and hired employees, as well as cotton growers, some of them more than once (interviews recorded in writing; many were home interviews with a protocol of 565 folio pages). Intensive participant observation was made as a shift worker along the focal plant's 3.5 month high season when it operated non-stop 24/7 and included visits to the other two shifts. My registrar job enabled me some writing during the shift and further details were added after it, resulting in 791 pages observation journal. Then I toured four other gin plants, observed their premises and interviewed 63 present and past executives and managers (331 page protocol). The longitudinal ethno graphing with free access to documents made it possible to check information and assertions, avoiding outsiders' naivety. Thick descriptions of managers' practices let me judge them as if I stood in their shoes. Moreover, I analyzed and re-analyzed my data several times over the last 30 years, returning from aggregate dimensions to 1 st order concepts [65].

Merkaz had two processing units in some 2000 and 2500 square meter halls full of large noisy machines connected by huge pipes and operated by some 240 electric motors of some 3000 horse power. The two together were capable of processing 650 tons of raw cotton daily during the high season, September-December, but mismanagement decreased production to an average of some 380 tons daily during my participant observation season. Raw cotton was brought to the yard and then to processing units in compressed stacks of eight ton on $6 \mathrm{X}$ 2.5 meter metal stretches which stood on 6 one-meter long iron legs transported by specially built tractor-pulled hydraulic carriages.

The main product, bales of quarter-ton cotton fibers, were stored in 3 stores, some 2000 square meters each, until shipped to spinning mills, mostly abroad, while the other product (seeds) was lorry-transported to oil extraction plants. Merkaz's permanent staff included 10 pe'ilim and 17 hired employees, supplemented by some 70 hired workers in the high season. 7 pe'ilim managed the plant: the PM, his deputy, the technical manager (hereafter TM), his deputy, the store manager, garage manager, and office manager. The plant was a part of Merkaz I-KRC owned by some 40 kibbutzim with some 12,000 inhabitants and handling much of their agricultural input and output in six plants with some \$US 350 million sales (One billion in current prices; [69]. It was administered by some, 200 pe'ilim and operated by some 650 hired employees. Kibbutzim received uniform salaries for pe'ilim's work, whose formal term of office was five years, in accord with the supposedly egalitarian rotatzia (rotation; e.g., [70] norm at kibbutzim, but senior pe'ilim violated it, retaining jobs for decades or moving from one managerial job to another, hence it enhanced oligarchization instead of curbing it [71]. Interviews of Merkaz CEO and 23 executives raised the suspicion that they were mostly ignorant of plants' uncertainty domains of technical, operational, and skilled manpower problems [38]. When touring plants I discerned obliviousness to inefficiencies and ineffectiveness, and found that growth and technological virtuosity received preference to obtain power, prestige, privileges, and tenure $[72,73]$. Coping with the problems of plants' uncertainty domains, inefficiencies, and ineffectiveness, was learned exclusively on-the-job, hence I held mini-seminars with nationally renowned veteran ginning experts, learned plants' problems and acquired considerable "knowthat" before learning "know-how" [20] by participant observation as registrar. I was so knowledgeable that technicians and foremen asked me why I would not succeed their intelligent and educated but ginning ignorant PM Shavit. Then I studied less intensively four other gin plants and found that only 4 of 27 outsider executives studied, three PMs and one CEO, were effective knowledgeable job-competent. These findings corresponded with critique by top ginning expert Arbiv, a past TM of Northern Gin Plant who became an R\&D engineer at the US labs of the world's largest ginning equipment manufacturer:

"The manager of the Valleys Gin Plant who also headed the national Gin Plant Association reached the conclusion that a good technical manager is just a good mechanic and did a bad service to the entire industry. Take Gornitzki from the Valeys Gin Plant - he's an excellent mechanic but during his first five years as technical manager he had no idea about cotton. Fortunately for him, he had two senior shift foremen who did know something about it and saved him... And do you think he knows anything about it today? Did you see the automatic feeder he designed? Did you see how he failed with the feeder he wanted to construct by himself to save US $\$ 20,000$ and avoid purchasing it from an experienced manufacturer?"

Observing this failure and a few others when visiting the four plants, including the failed Gornitzki's feeder, clarified the large gap between a good mechanic and a professional TM of high-capacity automatic gin plant. This gap was indicated by another top-level expert based on his twenty years of experience as the head of national cotton fiber grading laboratory, a graduate of a professional school in Mississippi whose lab's grading decided Israeli cotton fiber bales' market value

"Only very few people knew the [ginning] trade at each gin plant there was the administrative [plant] manager who did not last long, a $p a^{\prime} i l$ whose circulation decided continuity rather than the gin plant [needs], this was the worst defect, because until one learns the subject... a plant manager needs at least 5-6 years. The professionals who did the ginning, its changes and innovations were hired mechanics, often good mechanics who knew nothing about cotton - there was a huge gap between [knowing] the technical side and understanding cotton. The Gin Plant Association provided some training which was minimal, some [professional] Americans were invited to train these technicians, but often the latter did not have enough know-how to overcome the complex problems.

My data corroborated these portrayals of gin PMs and TMs, but my explanation of the etiology of their ignorance and incompetence differs meaningfully. Here is one example before my explanation: in 1968-9 some US gin plants invented a raw cotton transportation system using a special lorry called Mover which self-loads an eight-ton compressed stack, and then transports and unloads it into an automatic feeder which feeds the cotton into the ginning process (Figure 1).

An Israeli cotton industry delegation saw this system at work in 1971 but it was only adopted a decade later. During this period the booming Israeli cotton industry heavily invested in expanding the locally invented and built tractor-pulled carriage transportation system. Merkaz alone used some 100 such carriages and some 2000 metal stretches which transported cotton from as far away as 50 kilometers, meaning a two hour drive instead of a lorry's 45-50 minutes. In the early 1980s the efficient Mover system plus automatic feeders spared some 85 drivers plus 12 workers at the two processing units. Cost could not explain the Mover system's delay for a decade; enlargement of the less efficient transportation system to suit needs was no less costly, while sparing of its extra operation costs would have repaid the investment in Movers + automatic feeders within a few years (Figure 1).

\section{A summary of previously published findings on managerial ignorance}

Previous publications depicted and explained ignorance and job- 
Citation: Shapira R (2015) Ignorance-exposing Vulnerable Involvement, The Trust-creating Practice that Makes Executives Job-competent. J Socialomics 5: 144. doi:10.4172/2167-0358.1000144

Page 4 of 9

Three Generations of Raw Cotton Transport Technology

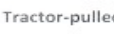
Cages (1960s)
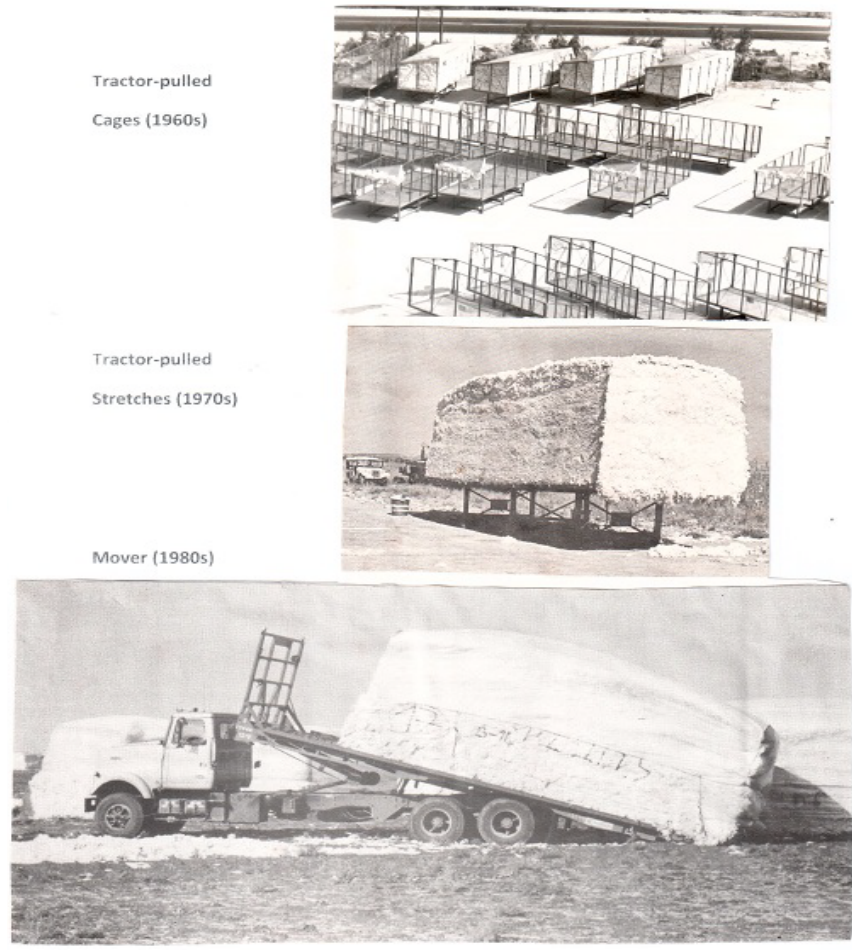

Figure 1: Three generations of raw cotton transport technology.

defending conservatism of most outsider PMs and I-KRC CEOs whose ignorance, job-defending conservatism and low-moral careerism explains the costly deferring of the above innovations [19,31,34,74,75] All these executives were pe'ilim "parachuted" to their jobs, a term used in Israel for the direct import of high-status outsiders to executive offices without prior experience of lower echelons, in the present case the ginning industry [18]. Deficient of pertinent know-how and phronesis for jobs, which were formally restricted to 4-5 years in accord with the kibbutz rotatzia (rotation) norm, they mostly avoided trustcreating ignorance-exposing vulnerable involvement, retaining their jobs, and defended authority by concealing/camouflaging ignorance through either detachment or seductive-coercive autocracy of secrecy, scapegoating, abuses, and subterfuges that led to mistakes and failures $[29,36,52]$ These however, often did not cause replacement for various reasons: Failing PMs helped CEOs camouflage/conceal failures, nepotism, and other ties ensured PMs' unquestioned support for CEOs, retention of failed PMs saved the face of nominating CEOs and a CEO ignorant of his own ignorance [76] missed the PM's ignorance and how his "riding" on successes of vulnerably involved mid-levelers camouflaged and concealed his mistakes and failures. Major mistakes by PMs and consequent debacles made their firing inevitable but even then in the case of PM Shavit's debacle the CEO delayed succession for almost a year to save his own face as nominator and mentor and create an image of normal rotatzia rather than firing the failing manager, which let Shavit further his managerial career elsewhere [31,34].

Worse still, the contextualizing of PMs' practices found that the majority choice of avoiding trust-creating vulnerable involvement was encouraged by the dysfunctional rule of I-KRCs by "parachuted" CEOs who mostly remained detached and ignorant and defended jobs by abuses and subterfuges rather than seeking effectiveness through trust creating vulnerable involvement and learning: among the 10 CEOs in the 5 I-KRCs studied only one, Dan of Northern I-KRC, chose ignorance-exposing vulnerable involvement in deliberations of its gin plant and encouraged similar involvement and virtuous trust and learning cycles among PMs and TMs, leading to distinctive efficiency and effectiveness (below). All other CEOs were more or less detached and ignorant of major plant problems hence they often did little if anything with plants' mediocre functioning or even failure due to PMs' ignorance out of either detachment or seductive-coercive involvement. In the case of PM Shavit's debacle during my participant observation, not once did I see the Merkaz I-KRC CEO visit the dysfunctional plant throughout the 3.5-month fiasco that drastically reduced production. The institutionalization of norms of rotatzia and "parachutings" served CEOs' rule by legitimizing the import and replacement of pe'ilim as PMs and TMs according to their loyalty to the bosses. Importees mostly followed in bosses' footsteps, engendering vicious distrust and ignorance cycles of secrecy, subterfuges, mistakes, and failures. However, total failures which might have encouraged CEOs' replacement spared the import of pe'ilim rescuers who due to pertinent expertises, habituses, and career advance prospects through excelling in, jobs chose vulnerable involvement, created high-trust local cultures through virtuous trust and learning cycles, and succeeded. Successes empowered them (Klein, 1998), so that ignorant superiors who felt threatened, suppressed them, and they left (see Thomas's case below). New pe'ilim were imported, opted for ignorance concealment, failed, and were replaced by rescuer pe'ilim who succeeded by trust and learning cycles, were empowered and suppressed, and so on; this seesaw prolonged rule by dysfunctional ignorant CEOs and PMs. The next section presents the opposite cases.

\section{Managerial Learning and Job-Competence: Trust- Creating Ignorance-Exposing Vulnerable Involvement}

As mentioned, much research indicates that trustful relationships are essential for knowledge sharing, learning, problem-solving, decision making, and innovation, as also suggested by above findings of mismanagement by distrusted job-ignorant executives. However, research also indicates the elusiveness of learning-enhancing high-trust cultures, requiring anthropological study of executives' practices to explain trust and learning cycles [75]. Ignorance-exposing vulnerable involvement is a prime signal of one's trust in others' benevolence, but other trustful practices are also needed, i.e., proofs of integrity, predictability, and competence (Dietz \& Den Hartog, 2006) by making right decisions and actions which are "morally correct [as] the interests of society take the degree of precedence that is right, just, and fair over the interests of the individual [57]. However, societal, communal, and organizational interests may differ, and what is right, just, and fair also depends on professional/generational/spatial norms and group/ subjective views. These views and expectations are impacted by actors' habituses [33] which have been shaped by both present and earlier cultures/sub-cultures [77].

In addition, trustworthy behavior tends to mutuality and creates ascending spirals: Ego's signaling trust, for instance, by sharing information, is reciprocated by Other's imparting his know-how; as Other proves trustworthiness Ego furthers trusting acts such as allowing Other more discretion [78]. Accordingly, leaders create high-trust cultures by open and sincere communication through vulnerable involvement, learning, and making morally correct and organizationally right decisions and actions, allowing employees discretion that enhances autonomy, competence, participation in problem-solving, and relatedness [79]. In these cultures employees 
are largely motivated by trust of and consent with officers who behave ethically, while communicating agreed-upon goals to which employees commit themselves [80]. They prove their integrity by minimal use of seductive and coercive means, use trustworthy practices and care for employees' long-term interests such as tenure, resulting in sharing of knowledge, effectiveness, adaptability, and innovation [58,72,75,81] let me demonstrate these in the few cases of vulnerably involved PMs.

\section{High-trust culture of three excelling vulnerably involved northern gin PMs}

After studying Merkaz I studied four other plants by interviews and observations of 5 CEOs, 8 PMs, 10 TMs, and 40 of their staffs, and through these interviews and documents I also acquired information on 10 additional PMs and 5 CEOs. Of all 22 PMs studied only one, Gabi of the Northern Gin Plant, learned ginning thoroughly by vulnerable involvement helped by a practical engineering education and much mechanical experience and encouraged by the high-trust culture created by his vulnerably involved predecessor, the pa' $i$ who founded the plant but learned ginning less than Gabi lacking mechanical knowledge. He participated in installing equipment and running a trial operation, was vulnerably involved in major problem-solving efforts, enlisted qualified TM Arbiv, cared for staff members' professional development, and for their personal needs, not only fair salaries but other needs as well. For instance, a young promising technician who later succeeded Arbiv decided to marry his fiancé but they could not find an apartment in the nearby town; when interviewed 20 years later he remembered the first PM using his ties in the dominant Mapai party and personally begging officials until finding an apartment. Gabi continued this caring policy but due to referred expertise he involved himself more in the staff's problem-solving beside hired TM Arbiv. Northern plant excelled for Gabi's eight years until succession, not only attaining less than $3 \%$ downtime in most seasons versus Shavit's Merkaz 32\% downtime in my participant observation season, but also on all other efficiency and effectiveness measures, primarily fiber quality which was cotton growers' prime concern as it decided fiber prices. The other nine Israel's gin plant managers acknowledged Gabi's excelling and chose him as their Association head and representative vis-a-vis the authorities.

I did not witness his management, coming to Northern years after his succession and leaving kibbutz, frustrated by the region's kibbutzim choice of a new I-KRC CEO who replaced committed effective plant managers with his ignorant low-moral careerist loyalists as did most CEOs [38]. I interviewed 12 of Gabi's role partners, including two CEOs, two of his successors, and their CEOs, as well as Gabi twice at length, since he knew a lot about other gins' PMs and CEOs. Gabi's expertise is also explained by a habitus of involvement, retained from participative management of his kibbutz field crops branch, and by his referred expertise as an ex-mechanic of cotton equipment which all the other 21 PMs lacked. His thorough learning of ginning enabled him to nurture highly professional TMs and staff, not only Arbiv and his successor but also others such as the deputy TM with whom I toured the plant. Arbiv left for the US, attracted by a generous salary to the $\mathrm{R} \& \mathrm{D}$ lab of the world's largest ginning equipment manufacturer. Then Gabi promoted Arbiv's deputy to TM, whose dozen years' experience made him a major expert as testified by Merkaz's expert TM Thomas (below) and other TMs. The TM's deputy did show me many small but significant technical improvements of the plant's machinery which prevented blockings like those from which we operators suffered so often at Merkaz [38], proposed by operators and technicians, those who suffered the hardships of coping with blockings. The three trust- nurturing Northern's PMs and the two TMs encouraged staff seeking such improvements, as the trustful culture ensured that employees empowered by successes of their improvements would not try to curb superiors' authority. The trustful culture was nurtured by the PMs being servant leaders [82] and "socialized leaders," unlike most of the PMs studied who were "personalized leaders" in Northern PMs' actions and decisions "the interests of society $\mathrm{t}[\mathrm{ook}]$ the degree of precedence that [was right, just, and fair over the interests of the individual] [57].

Gabi did not make a turnaround like Guest's car plant new manager or like Elena Kagan at Harvard Law School but his success resembled theirs and Thomas's at Merkaz (below) as it achieved continuous collaborative learning, problem-solving, and innovating efforts which he led while others contributed significantly [23]. Problems were solved one by one, often requiring creative innovations that used others' improvement motivation. For instance, a prime goal was better fiber quality and a major factor was giving each 8-ton stack different drying treatment according to varied raw cotton humidity in addition to noticing the changing air humidity and heat. ${ }^{1}$ This required several measurements of each stack, a time consuming task which I never saw anyone doing at Merkaz where drying treatment was decided intuitively when raw cotton was processed, meaning that often about one-third of the stack was processed before the operator changed boilers to suit its humidity. Gabi bought and gave each grower a hygrometer and each stack was brought to the plant yard with predetermined humidity, helping operators greatly. Moreover, this practice taught everyone that the plant's mission is to best serve the cotton grower's interest in highest fiber quality, one explanation how Northern achieved top fiber quality during the trust-nurturing PMs years.

Gabi was nominated to his job by CEO Dan, himself a vulnerably involved highly trusted executive, contrary to nine other I-KRC CEOs on whom I have information. I did not interview Dan but Gabi and others testified to his considerable involvement and lack of any attempt to distance himself from lower echelons; his involved backing was essential because Gabi used unconventional practices. For instance, almost all gin plants imported pe'ilim to replace hired TMs, while Gabi retained hired TM Arbiv nominated by his predecessor and when he left Arbiv's hired deputy became TM. By this insider promotion of the best ginner Gabi enhanced the high-trust culture and its dictum "what's best for the cotton will always receive the highest priority" to which the other two PMs and the two TMs adhered. Unlike low-moral power politics by most studied PMs [52], high-moral Gabi proved integrity, his deeds followed his words [83], commitment to the fiber quality goal was rewarded by promotion and remuneration and by taking the hired TMs to professional meetings of gin PMs and TMs in which they were the only non-pe'ilim present, a deed that aroused bitter criticism of both Gabi and his successor by other PMs. Gabi and employees "constituted and reconstituted" ginning know-how and phronesis by "engaging the world of practice" [7] and the managers successfully honed knowledge assets into sharper resources that advanced the plant's prime goal [21].

All these findings point to the critical role of trust-creating ignorance-exposing vulnerable involvement in engendering a hightrust culture in which executives freely admit ignorance, assured that no employee would use it against them, and learn from and with knowledgeable employees to become competent and achieve effective job functioning. However, the creation of such a local culture requires the collaboration of mid-levellers. This untangles the analysis of practices that led Merkaz's TM Thomas to professional excelling.

${ }^{1}$ In some $35^{\circ}$ Celsius November days with $10-15 \%$ humidity due to eastern winds, Merkaz operators even did not lit boilers to dry the raw cotton. 


\section{TM Thomas excelled by practices that nurtured a shop-floor high-trust culture}

Merkaz TM Thomas exemplified managerial trustful practices which accompanied vulnerable involvement and produced a shopfloor high-trust culture that enhanced effective plant functioning and innovation. Northern PM Gabi continued his predecessor's shaping of such a plant culture, while Thomas created a shop-floor high-trust culture beneath the plant's low-trust culture ruled by ignorant PMs Shavit and his predecessor Yuval, whose seductive-coercive amateur autocracy resembled [44] "parachutist."

Thomas (aged 35) was called to the rescue of Merkaz, where ignorant detached $p a$ 'il TM Avi had failed miserably [19]. Officially, Thomas was called the "Second TM" and Avi retained his formal status to serve the bosses' power interests [38]. As an experienced mechanic of agricultural machinery and a garage manager Thomas's vulnerable involvement continued an 18-year habitus of repairing machines by diving into their bellies and learning their secrets in a community of practitioners [8]. He had done this from the age of fourteen, when he worked three hours a day during high school, and then in the army as tank technician. He enjoyed psychological safety [84], did not worry about coping with the plant's technical problems, while a kibbutz garage democratic habitus of consulting others before deciding complex major mechanical questions encouraged vulnerable involvement in ginning practitioners' problem-solving efforts that enhanced his learning.

However, his self-assurance that encouraged involvement also enhanced conflicts with two senior veteran technicians, one of whom was Levi the informal deputy TM considered by all employees heir apparent of veteran TM Muli, and the other was Levi's assistant. When Muli left "parachutist" Avi replaced him and as he soon failed, Thomas was called to the rescue, and became de-facto TM with Avi assisting him. These two "parachuting's" frustrated the two technicians who expected promotion and incited clashes with Thomas for a year and half until they left. Thomas admitted making greenhorn mistakes while the two technician objections challenged his expertise and sensitized him to his own ginning know-how limits, encouraging vulnerable involvement, working 15-18 hours a day in the high season, and learning tacit knowledge both from his own experience [4,5] and from a few employees who began trusting him due to his commitment to tasks, and shared know-how and phronesis with him. His ample mechanical know-how enhanced communication and helped him solve problems that created ascending virtuous trust spirals as he trusted employees and allowed them discretion (Fox, 1974). Then more experts trusted him and exposed more secrets that furthered his expertise, he made wiser decisions that enhanced their trust, and this cycle continued, creating an innovative-prone high-trust local culture [79]. He became a leading ginning expert in Israel and like Arbiv he was invited to join the US R\&D department of the world's leading ginning equipment manufacturer but declined the invitation for personal reasons.

A major factor in Thomas's successful learning was the support by deputy-PM Danton and two other involved pe'ilim, the chief electrician and the garage manager. The collaboration of the four vulnerably involved pe'ilim transformed the low-trust shop-floor culture that Thomas found when coming into a local high-trust culture in which know-how and phronesis were learned by reflection-in-action [85] and solving problems in a community of practitioners created an "us" feeling [79]. This had happened both on the shop floor while coping with failed/broken machines and on the benches in the shade in front of the offices where mostly Danton who was in charge of yard operations and less frequently Thomas congregated with hired employees. Without prior knowledge, it was impossible to discern managers from foremen and workers, all wore dirty working clothes; only if one arrived towards the end of a discussion one could have seen that Danton or Thomas concluded what had to be done and all departed to do it. Most prior discourse was egalitarian and included an occasional dirty joke by a worker that sometimes pinned down a manager or foreman. Less frequently, the electrician and the garage manager dropped by, while neither distrusted PM Shavit nor Avi participated in these meetings.

However, Thomas's successes empowered him [5], so that detached ignorant PM Shavit felt threatened by his rising power, suppressed him, used red tape to postpone his invention of an automatic feeder for three years, and after its success Thomas left. As depicted at the end of the previous section his period was one phase in the seesaw that maintained the rule of Merkaz by dysfunctional ignorant CEOs and PMs [10,31].

\section{Discussion, Conclusions, and Plausible Solutions}

A semi-native multi-case anthropological study of outsidermanaged automatic processing plants emphasizes the decisive role of acquiring local tacit know-how and phronesis by trustcreating ignorance-exposing vulnerable involvement in practitioner communities' problem-solving for executives' job-competence. Such involvement engendered virtuous trust and learning cycles which made executives job-competent, taught local practices, their languages, and endowed interactional and contributory expertises. The "parachuted" executives studied mostly chose otherwise, causing vicious distrust and ignorance cycles; outsiderness [15] impacted choices by expertise deficiency, and power tempted its use to conceal ignorance and incompetence as dark secrets and to survive in jobs by power and information abuses, scapegoating, and subterfuges. Executive job-competence requires sensitivity to the unique contours of circumstances, which require local know-how and phronesis, some of which is unknown even to insiders, as with promotion they take charge of unfamiliar units/ functions. Ignorance-exposing vulnerable involvement in employee's deliberations is required to gain their trust and knowledge sharing, to learn this know-how and phronesis and to become job-competent, but this requires jeopardizing one's authority until becoming job-competent.

Job-ignorant executives mostly retained their authority and jobs and advanced careers despite job incompetence by "riding" on midlevelers' successes. The latter created trust and learning cycles and hightrust innovation-prone shop-floor cultures by vulnerable involvement and cooperative relationships with like-minded employees who were allowed much discretion for problem-solving [78]. These employees shared their know-how and phronesis acquired by hard work and learning from experience only with trustworthy superiors whose ignorance exposure proved a genuine wish to learn and solve problems for the common good. Only socialized leaders committed to organizational goals, and not personalized leaders were trusted and became truly job-competent, but contrary to kibbutz socialist ideology, I-KRC practices encouraged personalized leaders by promotion largely decided by ties with and loyalty to higher-ups rather than by successful functioning, while the rotatzia norm shortened terms and made the learning of local knowledge less worthwhile [31,70,74].

Incompetence was prevalent among outsider executives, up to $85 \%$ : only 4 of the 27 studied were vulnerably involved in problem-solving by ginners and technicians' communities, learned their language, and acquired interactional expertise and contributory expertise. They led Northern to excel over all others by a high-trust innovation-prone 
Citation: Shapira R (2015) Ignorance-exposing Vulnerable Involvement, The Trust-creating Practice that Makes Executives Job-competent. J Socialomics 5: 144. doi:10.4172/2167-0358.1000144

Page 7 of 9

culture dedicated to best serving cotton growers. All the rest avoided being "inextricably immersed" in "an unceasing flow of activities" in the gin plants, in which "practical wisdom and judgment" developed [1]. Detached PMs managed to conceal ignorance and incompetence by "riding" on the successes of subordinates: 7 of the 10 TMs studied were vulnerably involved knowledgeable job-competent. ${ }^{2}$ The large difference between $70 \%$ of TMs who succeeded by trustful involvement that endowed job competence versus only $15 \%$ of executives, is not a sampling bias; these statistics include all TMs versus all PMs and 5 CEOs. ${ }^{3}$ Moreover, it includes the two plants, Northern and Southern, known in the industry as the best managed, thus the 5 plants sampled were above the average with managerial competence. In accord with our theory, the large difference is explained by different habituses, referred expertises, and career prospects that encouraged contrary choices: TMs came from the inside or from minor kibbutz managerial jobs, mostly habituated of vulnerable involvement in practitioner communities, enjoyed referred expertise, and their prospects for career advancement in the kibbutz field were meagre, hence palpable job success was essential for outside promotion like Arbiv's and the offer to Thomas; these factors encouraged vulnerable involvement. PMs and CEOs, on the other hand, came mostly from full-time managerial jobs in which avoiding failures by conservatism and loyalty to higher-up advanced careers; this discouraged taking risks of ignorance exposure and encouraged common managerial job-defensive strategies [28,29,52].

The PMs studied mostly emulated their appointers, CEOs who mostly ruled I-KCs over time with no ignorance-exposing vulnerable involvement nor trustful learning primarily because whenever a threat of total failure became imminent due to mistakes and failures of ignorant PMs Thomas-like rescuers came from the kibbutzim [38]. Thus, a prime remedy is avoiding the "parachuting" of CEOs and PMs, manning executive jobs by trustworthy knowledgeable insiders whose local and industry knowledge, referred expertise, and considerable acquaintance with staff members encourages trust-creating vulnerable involvement leading to successful high-moral leadership in accord with literature that points to insider superiority [86,87]. Moreover, often outsiders are brought as saviors [18] while inside-outsiders or outsiders with inside knowledge and personal acquaintance have better chances of creating trust and succeeding than outsiders without these resources [17].

Preventing failed "parachutings" requires anti-oligarchic succession norms for CEOs, since a major reason for failures is oligarchic selfperpetuation in dysfunction phases [88]. Rotatzia proved oligarchyenhancing in the kibbutz field and failed in other organizations as well [70] Succession encouraged by Golden Parachutes is mostly oligarchic; these are allotted independently of a CEO's functioning on the job [89] with no say to non-director executives and managers who know, best whether s/he deserves generosity. Successes of democratic firms $[46,86,90]$ suggest that a democracy which includes knowledgeable insiders in succession decisions side by side with directors can curb oligarchic tendencies by periodic tests of trust in a CEO, say every four years like the reelection of US presidents. However, the many cases of successful leaders who managed to function effectively for more than eight years support allowing executives more than two terms. This is plausible by allowing up to four terms for those trusted by extra-large majorities, over $67 \%$ for a third term and over $88 \%$ for a fourth term [34].

${ }^{2}$ Details of these executives, their TMs and other mid-levelers will be presented in a book I am writing.

${ }^{3} 5$ other CEOs were not studied, as interviewees described them as similar to the 4 ignorant ones.
A third measure can be the defining of new yardsticks for executive selection that minimize the chances of their opting for ignorance concealment:

1. Having, a habitus of vulnerable involvement aimed at learning local problems,

2. Having referred and interactional expertises that fit a firm's major problems,

3. Previous successful trustful servant transformational leadership [80].

These yardsticks may also be useful for comparing insider versus outsider candidates, but further study of their relative weight in foreseeing who among candidates will choose trust-creating vulnerable involvement is in order. Research is also required of the relative weight of the various factors that impact this choice:

1. Involvement habitus

2. Relevancy of expertises

3. Previous leadership style

4. Perceived career prospects of alternative advancement routes

5. Organizational contexts that encourage/discourage each choice

A radical change of attitude to the study of competence acquisition by executives is needed to further untangle, for instance, how they acquire "special sensitivity to the unique contours of the circumstances in which [they] happen to operate each time" [1,2]. Beside the factors studied here this sensitivity is seemingly impacted by personal histories and cultural contexts thus requiring more longitudinal ethnographies; these can result in an organizational science that matters [4]. Such studies must be much longer and extensive than a usual organizational ethnography, and they must be phronetic, seeking a concrete, practical, and ethical answers to major troubling questions concerning powerholders of one's society, much as the Aalborg Project was for [4] and the study of kibbutz for myself [74].

\section{References}

1. Shotter J, Tsoukas H (2014) In search of phronesis: Leadership and the art of judgment. Academy of Management Learning \& Education 13: 224-243.

2. Heifetz RA (1995) Leadership without Easy Answers. Cambridge (MA): Belknap.

3. Fine GA (2012) Tiny Publics. New York: Russell Sage, Newyork, USA.

4. Flyvbjerg B (2006) Making organization research matter: Power, values and phronesis. Sage Handbook of Organization Studies 357-381.

5. Klein G (1998) Sources of Power. MIT Press. Cambridge (MA), USA.

6. Klein JA (2004) True Change. Jossey-Bass, San Francisco, USA.

7. Orlikowski WJ (2002) Knowing in practice: Enacting a collective capability in distributed organizing. Organization Science 13: 249-273.

8. Orr JE (1996) Talking About Machines. Cornell University Press Ithaca Newyork, USA.

9. Schweigert FJ (2007) Learning to lead: Strengthening the practice of community leadership. Leadership 3: 325-342.

10. Shapira R (1987) Anatomy of Mismanagement. Am Oved. Tel Aviv.

11. Townley B (2002) Managing with modernity. Organization 9: 549-573.

12. Shotter J, Tsoukas $H$ (2014) Performing phronesis: On the way to engaged judgment. Management Learning 45: 377-396.

13. Flyvbjerg B (2001) Making Social Science Matter. Cambridge University Press USA. 
Citation: Shapira R (2015) Ignorance-exposing Vulnerable Involvement, The Trust-creating Practice that Makes Executives Job-competent. J Socialomics 5: 144. doi:10.4172/2167-0358.1000144

Page 8 of 9

14. Blau PM (1955) The Dynamics of Bureaucracy. University of Chicago Press, USA.

15. Karaevli A (2007) Performance consequences of new CEO 'outsiderness' Moderating effects of pre-and post-succession contexts. Strategic Management Journal 28: 681-706.

16. Bower JL (2007) The CEO Within. Harvard Business School Press, Boston, USA.

17. Johnson C (2008) The rise and fall of Carly Fiorina: An ethical case study. Journal of Leadership \& Organizational Studies 15: 188-196.

18. Khurana R (2002) Searching for a Corporate Savior. Princeton University Press, Newyork, USA.

19. Shapira R (1995) 'Fresh blood' innovation and the dilemma of persona involvement. Creativity and Innovation Management 4: 86-99.

20. Brown JS, Duguid D (2001) Knowledge and organization A social-practice perspective. Organization Science 12: 198-213.

21. Wagner RK (2002) Smart people doing dumb things: The case of manageria incompetence. Why Smart People Can Be So Stupid, Yale University Press $42-63$

22. Tsoukas H (2005) Complex Knowledge. Oxford University, USA.

23. Bennis W (1991) Why Leaders Can't Lead. San Francisco: Jossey-Bass.

24. Guest RH (1962) Organizational Change. Tavistock, London, UK.

25. Zand DE (1972) Trust and managerial problem solving. Administrative Science Quarterly 17: 229-239

26. Dore R (1973) British Factory - Japanese Factory. University of California Press, Berkeley,USA.

27. Lee P, Gillespie N, Mann L (2010) Wearing A Leadership and trust: Their effect on knowledge sharing and team performance. Management Learning 41: 473491.

28. Dalton M (1959) Men Who Manage. Wiley, New York, USA

29. Jackall R (1988) Moral Mazes. Oxford, New York, USA.

30. Linstead S, Marechal G, Griffin RW (2014) Theorizing and researching the dark side of organization. Organization Studies 35: 165-188.

31. Shapira R (2015) Prevalent concealed ignorance of low-moral careeris managers: contextualization by a semi-native multi-site Strathernian ethnography. Management Decision 53: 1504-1526.

32. Grove AL (1996) Only Paranoid Survive. Doubleday, New York, USA.

33. Bourdieu P (1990) The Logic of Practice. Polity, Cambridge, USA

34. Shapira R (2013) Leaders vulnerable involvement: Essential for trust, learning effectiveness and innovation in inter-co-operatives. Journal of Co-operative Organization and Management 1: 15-26.

35. Collins HM, Sanders G (2007) They give you the keys and say 'drive it' Managers, referred expertise, and other expertises. Studies in History and Philosophy of Science 38: 621-641.

36. Gittell JH (2000) Paradox of coordination and control. California Management Review 42: 101-117.

37. Burns T, Stalker GM (1961) The Management of Innovation. Tavistock London, UK.

38. Shapira R (2015) Dysfunctional outsider executives' rule and the terra incognita of concealed managerial ignorance. Open Journal of Leadership 4: 12-29.

39. Buckingham M, Coffman C (1999) First Break All the Rules. Simon and Schuster, New York, USA.

40. Luthans F (1988) Successful versus effective managers. Academy of Management Executive 2: 127-132.

41. Bratton VK, Kacmar KM (2004) Extreme careerism The dark side of impression management.

42. Weissberg R (2002) Administrative careerism and PC. Academic Questions 15: $58-68$.

43. Wilson GI (2011) Careerism, The Pentagon Labyrinth: Center for Defense Information, Washington, USA. 43-59.
44. Gouldner A (1954) Patterns of Industrial Bureaucracy. Free Press, New York USA.

45. O'Mahoney JK (2005) Trust, distrust and anxiety: The new manufacturing philosophy at Gearco.

46. Semler R (1993) Maverick Warner, New York, USA.

47. Harvey-Jones J (1988) Making it Happen. Fontana, London, UK.

48. Poulin BJ, Hackman MZ, Barbarasa Mihai C (2007) Leadership and succession The challenge to succeed and the vortex of failure. Leadership 3: 301-325.

49. Washburn KK (2011) Elena Kagan and the miracle at Harvard. Journal of Legal Education 61: 67-75.

50. Simons T (2002) Behavioural integrity: The perceived alignment between managers' words and deeds as a research focus. Organization Science 13 $18-35$.

51. Thoms JC (2008) Ethical integrity in leadership and organizational mora culture. Leadership 4: 419-442.

52. Mehri D (2005) Notes from Toyota Land. ILR Press. Ithaca, NewYork, USA.

53. Ciulla JB (1998) Leadership and the problem of bogus empowerment. Ethics, the Heart of Leadership: Westport (CN) Praeger 63-86.

54. Courpasson D, Clegg S (2006) Dissolving the Iron Cages? Bureaucracy and the perpetuation of elite power. Organization 13: 319-343.

55. Dietz G, Den Hartog DN (2006) Measuring trust inside Organizations. Personne Review 35: 557-588

56. Cheng BS, Chou LF Wu TY, Huang MP, Farh JL, et al. (2004) Paternalistic leadership and subordinate responses: Establishing a leadership model in Chinese organizations. Asian Journal of Social Psychology 7: 89-117.

57. Hosmer LT (1995) Trust: The connecting link between organizational theory and philosophical ethics. Academy of Management Review 20: 379-403.

58. Ouchi WG (1981) Theory Z. Boston: Addison-Wesley.

59. Yanow D (2004) Academic anthropologists in the organizational studies workplace. Management Learning 35: 225-238.

60. Collins H (2011) Language and practice. Soc Stud Sci 41: 271-300.

61. Collins HM, Evans R (2007) Rethinking Expertise. Chicago. University of Chicago Press. USA

62. Collins J (2001) Good to Great. Harper Collins, New York, USA.

63. Welker M, Partridge DJ, and Hardin R (2011) Corporate lives: New perspectives on the social life of the corporate form. Current Anthropology 52: 3-15.

64. Narayan K (1993) How native is a 'native anthropologist'? American Anthropologist 95: 671-686.

65. Gioia DA, Corley KG, Hamilton AL (2013) Seeking qualitative rigor in inductive research: Notes on the Gioia Methodology. Organizational Research Methods 16: 15-31.

66. Shapira R (2012) Becoming a triple stranger: Auto ethnography of a kibbutznik's long journey to discoveries of researchers' faults. Serendipity in Anthropological Research: Farnham, Ashgate, UK 93-108.

67. Fondas N, Wiersema M (1997) Changing of the guard: The influence of CEO socialization on strategic change. Journal of Management Studies 34: 561-584

68. Geertz C (1973) The Interpretation of Cultures. Basic Books, New York, USA.

69. Niv A, Bar-On D (1992) The Dilemma of Size from a System Learning Perspective: The Case of the Kibbutz. Greenwich (CN): JAI Press.

70. Gabriel RA, Savage L (1981) Crisis in Command. Himalyan, New Delhi, India

71. Shapira R (1995) The voluntary resignation of outsider managers: Interkibbutz rotation and Michaels's 'Iron Law'. Israel Social Science Research 10: 59-84.

72. Shapira R (1978) Autonomy of techno structure: Case study of a regional interkibbutz industrial organization. The Kibbutz 6: 276-302

73. Galbraith JK (1971) The New Industrial State. Houghton Mifflin, Boston, USA.

74. Shapira R (2008) Transforming Kibbutz Research. Cleveland (OH): New World Publishing. 
Citation: Shapira R (2015) Ignorance-exposing Vulnerable Involvement, The Trust-creating Practice that Makes Executives Job-competent. J Socialomics 5: 144. doi:10.4172/2167-0358.1000144

Page 9 of 9

75. Shapira R (2012) High-trust culture, the decisive but elusive context of shared co-operative leaderships.

76. Kruger J, Dunning D (1999) Unskilled and unaware of it: how difficulties in recognizing one's own incompetence lead to inflated self-assessments. J Pers Soc Psychol 77: 1121-1134.

77. Parker M (2000) Organizational Culture and Identity. Sage, London, USA.

78. Fox A (1974) Beyond Contract. Faber, London, USA

79. Haslam AS, Reicher SD, Platow MJ (2010) The New Psychology of Leadership. Psychology Press, New York, USA.

80. Sendjaya S, Sarros JC, Santora JC (2008) Defining and measuring servant leadership behaviour. Journal of Management Studies 45: 402-423.

81. Gillespie NA, Mann L (2004) Transformational leadership and shared values: The building blocks of trust. Journal of Managerial Psychology 19: 588-607.

82. Greenleaf RK (1977) Servant Leadership. Paulist Press. New York, USA.
83. Simon H (1957) Administrative Behavior. Free Press. New York, USA.

84. Edmondson AC (1999) Psychological safety and learning behavior in work teams. Administrative Science Quarterly 44: 350-383.

85. Schon DA (1983) The Reflective Practitioner. Basic Books New York, USA.

86. Erdal D (2011) Beyond the Corporation. Bodley Head, London, UK.

87. Groysberg B, McLean AN, Nohria N (2006) Are leaders portable? Harv Bus Rev 84: 92-100: 157

88. Michels R (1959) Political Parties. Dover New York, USA.

89. Vancil RF (1987) Passing the Baton. Harvard Business School Press. Boston USA.

90. Storey J, Basterretxea I, Salaman G (2014) Managing and resisting 'degeneration' in employee-owned businesses: A comparative study of two large retailers in Spain and the United Kingdom. Organization 21: 626-644. 